\title{
EUROPEAN REGIONAL INTEGRATION CASE STUDY OF ROMANIA
}

\author{
CARMEN BEATRICE PĂUNA \\ Economic Forecasting Institute, Romanian Academy \\ Calea 13 Septembrie No. 13, Casa Academiei, Sector 5 \\ Bucharest, Romania, RO - 050711 \\ e-mail: Pauna.Carmen@gmx.at

\section{DALINA MARIA ANDREI} \\ Economic Forecasting Institute, Romanian Academy \\ Calea 13 Septembrie No. 13, Casa Academiei, Sector 5 \\ Bucharest, Romania, RO - 050711 \\ e-mail: dalinaandrei@yahoo.com
}

\begin{abstract}
Romania after accession to the EU, on 1 January 2007, tried to find a strategy to optimize the integration of our country from economic, social, technological and environmental viewpoint.

A context in which Foreign Direct Investments (FDI) help the market economy comes as appropriate to the current world-wide political landscape, but equally create and enlarge contradictions.

Romania meat a new inflow of FDI after 2000, surpassing its neighbour countries year after year.

But the growth prospects for 2009 continue to deteriorate sharply, as the country is expected to suffer a strong deceleration of both the domestic and the external sectors.
\end{abstract}

Key words: regional disparities, european integration, regional development, financial and economic crisis, Foreign Direct Investment, convergenge to EU

\section{PERSPECTIVES OF THE EUROPEAN REGIONAL INTEGRATION CASE STUDY OF ROMANIA}

European Union Integration is profound and diversified process with respect to the forms taken by the instruments and mechanism for achieving it. After Romania's accession to the EU, on 1 January 2007, it was tried to find a strategy to optimize 
the integration of our country from economic, social, technological and environmental viewpoint.

The development disparities between the Member States and between the 255 regions (including Romania and Bulgaria) within EU's borders, measured by the GDP/capita, register significant high values, although there is a certain level of convergence in term of incomes in the EU-15, according to the 4th Progress Report for Cohesion, presented by European Commission on 12.06.2006. The socio-economic differences and the development imbalances between the territories of the EU are the main factors which impliy the community intervention through the regional policy. Thus the diminuation of the disparities between the most and less developed regions, quantified usually (as it was mentioned) in terms of GDP/capita represents the most important aim of the Cohesion Policy at EU level. For this purpose the most part of the EU funds are allocated to the regions which have a GDP/capita less than $75 \%$ of the EU average.

The EU Enlargement emphasized these econmic development inequalities, representing in the meanwhile an unique situation for the economic competitiveness and internal cohesion.

The aim of the new desired architecture of the EU is to focus the actions within three main themes, accordingly to Lisbon Agenda priorities, as it follows:

- designing the european regions as attractive econmic areas for investments

- promotion of innovation

- creation of more and better jobs.

Under the new circumstances of EU enlargement, the implementation of the Lisbon Strategy became an important piece of the cohesion policy reform.

For the period 2007-2013 the European Commission proposed the focusing of the Cohesion Policy on the following main objectives:

- Objective 1-regional development convergence: $2 / 3$ of the fund will support the regions where GDP/capita is less than $75 \%$ of the Community average (the new member states); $1 / 3$ will sustain temporarily the old states, that faces the statistical effect of the enlargement. For this objective are eligible 100 regions representing more than $35 \%$ of the EU-27

- Objective 2-regional competitiveness and employment, focusing on: innovation, environment and risk neutralization, and accessibility.

- Objective 3-European territorial cooperation (balanced territorial development)

The philosophy ${ }^{1}$ for using these fond consists in:

- Financial assistance principles

- A more pronounced strategic approach (based on the EU priorities)

- Decentralised and territorial approach with more responsibilities for the member states, regions and towns

- Simplifying the management methods.

\footnotetext{
1 According to the European Council Rule No. 1084/11.07.2006.
} 
Even though we will need in the future new integration and governance instruments and methods, we can still speak about a common model through the EU members, we mean the European Economic Model. Its objectives are focused on ${ }^{2}$ : "growth, social cohesion and employment based on increasing R\&D expenditures, on liberalising the services' industry, increasing employment and implicitly reducing unemployment". As many specialists already mentioned ${ }^{3}$, the European Economic Model "does not represent a rigid scheme, but a milestone aiming to more aspects", as for example:

- Social justice

- Increasing employment and diminishing unemployment

- A better adjustment between the structure of the educational system and the need of workplaces in society, and in research

- Diminishing the gaps between rich and poor at individual, social groups and EU member-states level, and counteracting the increase trend of these gaps.

The European Economic Model is regarded favourable not only by the European specialists but also by the American ones, as for example Jeremy Rifkin, who consider that "Europe is far better prepared to solve some issues such life quality, etc"4. But the European Economic Model has also many critics as well, as it is proven by the debates around the Constitutional Treaty, which has as main tasks: the European governance and at the same time "unity in diversity". Under these circumstances we wonder if we could speak anymore about the European Dream. One thing is true, that in the future it'll need new integration, governance instruments and methods and a new vision on public policies and business. This fact is stressed also by the actual situation of financial and economic crisis. More than that, the impact of the international economic crisis upon the new EU member states proved to be more severe than anticipated a few months ago.

The European Comission took the initiative to set out how decisive and coordinated action could respond to the economic crisis by developing an Europen Economic Recovery Plan by adopting two communications:

- $\operatorname{COM}(2008) 706$ „From financial crisis to recovery: A European framework for action", Brussels, 29.10.2008 and

- COM(2008) 800 final COMMUNICATION FROM THE COMMISSION TO THE EUROPEAN COUNCIL, A European Economic Recovery Plan, Brussels, 26.11.2008.

Regarding the economic crisis in Romania, the main changes to the socio-economic context started at the end of 2008 as a consequence of the economic crisis-all the socio-economic indicators registered an accelerated declining trend at the level of 2009: decrease in GDP growth rate, employment rate, number of SMEs, FDI inflows (Figure 1, Table 1).

\footnotetext{
2 Zaman, Gh. (2007) Strategic milestones of Romania's integration to the European Union process efficiency”, Theoretical and Applied Economics, Supplement, 2007.

3 Ibidem

4 Ibidem
} 


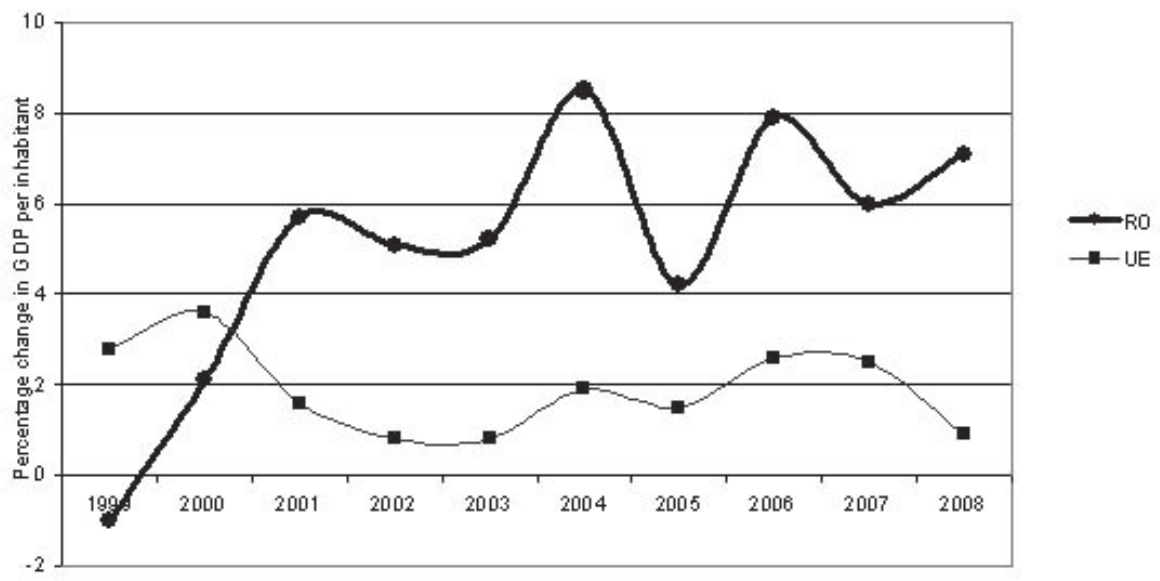

Figure 1. Romania-Changes in GDP/capita 1999 to 2008 Source: National Commission for Prognosis.

Table 1. Romania-Regional GDP/capita and regional disparity indices 2005 to 2008

\begin{tabular}{|c|c|c|c|c|}
\hline & 2005 & 2006 & $2007 \mathrm{e}$ & $2008 \mathrm{e}$ \\
\hline \multicolumn{5}{|c|}{ GDP per capita in Euros } \\
\hline North East & $2,526.8$ & $2,942.7$ & $3,333.2$ & $3,733.6$ \\
\hline South East & $3,137.0$ & $3,651.4$ & $4,124.4$ & $4,609.3$ \\
\hline South & $3,018.8$ & $3,519.9$ & $3,984.6$ & $4,454.2$ \\
\hline South West & $3,087.2$ & $3,606.2$ & $4,074.8$ & $4,546.8$ \\
\hline West & $4,223.5$ & $4,929.3$ & $5,563.2$ & $6,204.9$ \\
\hline North West & $3,422.4$ & $3,975.3$ & $4,495.0$ & $5,022.9$ \\
\hline Centre & $3,935.5$ & $4,590.8$ & $5,195.0$ & $5,799.5$ \\
\hline Bucharest Ilfov & $7,487.2$ & $8,875.5$ & $10,153.4$ & $11,416.3$ \\
\hline \multicolumn{5}{|c|}{ Disparity index of GDP per capita versus total country GDP } \\
\hline North East & 68.7 & 68.4 & 68.3 & 68.4 \\
\hline South East & 85.3 & 84.9 & 84.6 & 84.5 \\
\hline South & 82.1 & 81.8 & 81.7 & 81.6 \\
\hline South West & 83.9 & 83.8 & 83.5 & 83.3 \\
\hline West & 114.8 & 114.6 & 114.1 & 113.7 \\
\hline North West & 93.0 & 92.4 & 92.2 & 92.0 \\
\hline Centre & 107.0 & 106.7 & 106.5 & 106.3 \\
\hline Bucharest Ilfov & 203.5 & 206.3 & 208.2 & 209.2 \\
\hline
\end{tabular}

e: estimated

Source: National Commission for Prognosis. 
The regions' individual participation to the Gross Domestic Product (GDP) formation shows relatively constant weights in the last years. The most regions had weights included almost in the same interval (North-East, South-East, South-Muntenia, North-West and Center). As expected, the Bucharest-Ilfov region is, by far, the first contributor to the total Romania's GDP and its weight variations are low. The 20052008 interval shows a slow increasing of the Bucharest-Ilfov weight in the total GDP.

Regarding the Gross Domestic Product (GDP) structure in the same interval, the primary sector (see agriculture, wood and fish industries) was keeping a 7.8\% weight in the total GDP, on average. But, paradoxically, this average is overpassed by all regions, except for Bucharest-Ilfov. As for the rest of regions, the maximum disparity level (as between the highest and the lowest regional weights of the primary sector in GDP) stays about 4.4 percentage points (pp).

Industry of the individual regions differetnly contributed to the total GDP formation, as between a maximum wiight of $32.5 \%$ of the South-Muntenia and a minimum one of $17.0 \%$ of the Bucharest-Ilfov. Near to the maximal contribution, there are also to be found the Center (30.1\%) and South-West-Oltenia $(29.2 \%)$. The rest of the regions rather accounted for percentages around the national average $(24.5 \%)$.

Constructions contributed to the GDP by an average of $7.4 \%$ by regions. As above this percentage, there came the South-East (8.9\%), South-West-Oltenia (8.0\%) and Bucharest-Ilfov (8.9\%) and the rest of regions came in a much narrower percentage interval between $6.2 \%$ (South-Muntenia) and 6.7\% (West).

The third sector (the services) finally reached the highest contribution to GDP on both its total and regional sources. The services contribution to the total national GDP was $63.3 \%$, and the regions counting started by Bucharest-Ilfov (73.6\%), followed by North-East $(60.7 \%)$ and West $(59.1 \%)$. As below the national average there were to be found South-Muntenia (51.4\%) and South-West-Oltenia (52.8\%).

The civil employed population grew between 2002 and 2006 by 1.7\%, but with different dynamics among regions. As for instance, Sowth-East, correspondingly meat $1.3 \%$, West $3.0 \%$, North-West $2.0 \%$ and Bucharest-Ilfov 24.7\%. The other regions first meat lower wages, so employment was lower than the average.

The highest unemployment rate over the period 2005-2008 were in the Development Regions: South West, South and North-East, regions where the rural activities are predominent. There are clear disparities within regions where the counties that are predominently rural co-existing with more developed ones (for example, Teleorman county with $9.2 \%$ with Prahova country where the unemployment rate is of $4.6 \%$ ). Bucharest region and North-West region have the lowest rates of registered unemployed. These areas have specific advantages of a lower dependency towards the primary sector (Bucharest region), the proximity of the western markets (North-West region), an a better ability to attract direct foreign investments (both regions). The level of foreign direct investment (FDI) is recognised as a key contribution to GDP growth in Romania. The level of FDI has remained strong in the period from 2005 to 2008 (Table 2). 
Table 2. Romania-balance of FDI per region-2006 and 2007

\begin{tabular}{|c|c|c|c|c|c|c|}
\hline \multirow{2}{*}{ Region } & \multicolumn{2}{|c|}{2005} & \multicolumn{2}{|c|}{2006} & \multicolumn{2}{|c|}{2007} \\
\hline & $\mathrm{M} €$ & $\%$ & $\mathrm{M} €$ & $\%$ & $\mathrm{M} €$ & $\%$ \\
\hline Total & 21,885 & 100.0 & 34,512 & 100.0 & 42,770 & 100.0 \\
\hline North -West & 1,257 & 5.8 & 1,570 & 4.6 & 1,907 & 4.5 \\
\hline Centre & 1,610 & 7.4 & 2,559 & 7.4 & 3,541 & 8.3 \\
\hline North-East & 292 & 1.3 & 411 & 1.2 & 672 & 1.6 \\
\hline South - East & 1,838 & 8.4 & 2,653 & 7.7 & 2,448 & 5.7 \\
\hline South- Muntenia & 1,388 & 6.3 & 2,228 & 6.5 & 2,942 & 6.9 \\
\hline Bucharest-Ilfov & 13,264 & 60.6 & 22,205 & 64.3 & 27,516 & 64.3 \\
\hline South -West oltenia & 745 & 3.4 & 938 & 2.7 & 1,379 & 3.2 \\
\hline West & 1,491 & 6.8 & 1,948 & 5.6 & 2,365 & 5.5 \\
\hline
\end{tabular}

Source: National Bank of Romania, 2008.

Romania really caught-up in recent years, but there still seems to be much room for further FDI-inflows both in absolute and relative terms when compared to other CEECs. The per capita FDI in 2006 amounted to some 528 US-\$, what represents a big improvement but was still only undercut by Poland and (503 US-\$) and Slovenia (275 US-\$). Hungary attracted even 1,028 US-\$ of FDI per capita.

The Romania's upward FDI inflow trend continued after 2004, up to the last 2008. ARIS ${ }^{5}$ stressed that foreign direct investments attracted to Romania were possible due to a stable and foreseeable macro-economic context and by an attractive investment climate 6 .

A study carried out by the National Bank of Romania (NBR) and the National Statistics Institute (NSI) pointed out some more in this sense. Basically, 2008 was the ninth year of successive economic growth for Romania. The GDP registers a growth of around 7-8\%. The increase is mainly determined by the strong activity volume, especially in the services sector, industry and constructions. Yet, probably starting with October 2008 the GDP is supposed to have meat its decline, due to the international crisis which affected Romania as well.

The growth prospects for 2009 continue to deteriorate sharply, as the country is expected to suffer a strong deceleration of both the domestic and the external sectors. Meanwhile, at the end of 2008 international credit rating agencies Standard $\&$ Poor's and Fitch cut the country's credit rating to BB+, citing a lack of macroeconomic policies to respond to the mounting economic risks.

\footnotetext{
5 The Romanian Agency for Foreign Investments (ARIS 2008).

6 ARIS recent estimations put the full-year FDI volume at more than eight billion euros. At present, ARIS provides technical assistance and monitors 92 foreign investment projects, in ongoing implementation in Romania, in the total cumulated value of 11 billion euros. These investments are to create 37,000 new jobs. And according to ARIS (2008), as well, Romania will continue in the current 2009, as well, this FDI upward trend, the fields of interest being the auto and auto components industry, processing industry, bio-energy and IT and research-development sectors.
} 
The two involved Institutions calculated the balance of foreign direct investments in end-2007 and also how much foreigners have invested in Romania so far. Thus, the total direct foreign investments in Romania in the latest 18 years stood at 42.77 billion euros, in end 2007. From this amount, 31.50 billion euros (74\%) represented participations in the share capital, with the remaining 11.27 billion euros representing net credit from foreign investors.

As regarding the orientation of the foreign investors to certain economic sectors, more significant direct foreign investments were registered in the processing industry (32.9\% of the total). Other fields, which also attracted significant direct foreign investments, were in 2007: the retail and wholesale trade (14\%), constructions and real estate $(7.8 \%)$ and telecommunications $(6.5 \%)$. As for investing by economic sectors, the analysis shows a rise in the weight of investments made in farming (from 1.6\% in the first half of 2007 to $4.8 \%$ in the next year corresponding first half) and in industry (from $35.4 \%$ in half one of 2007 to $36.3 \%$ in this half one of 2008). Such rises have been accompanied by a dwindled weight of the investments in trade and services of the total investments made in the national economy, which points to the fact that a certain degree of maturity has been reached in this area, after high growth rates posted in the last years. Finally, the financial brokerage and insurance companies attracted no less than a quarter of the FDI last year in Romania, that is $23.3 \%$ of the total investments on the domestic market.

There has been also analyzed the geographical characteristics of the FDI, meaning the origins of inflows. Thus, more than a $1 / 5$ of the direct foreign investments carried out in Romania till the end of last year came from Austria. Despite the fact that Austria reduced its weight in the total direct foreign investments in Romania injected until December 31, 2007, by 1.6\%, down to $21.4 \%$, Austria is still ranking 1st among investors in Romania, according to the report of the Central Bank.

Austria was carrying out investments worth 9.16 billion euros in Romania late last year. Out of the total 42.77 billion euros in direct foreign investments so far in Romania, Bucharest attracted almost two thirds (64.3\%), more exactly 27.52 billion euros, followed from far behind by the central region (Alba-Iulia, Brasov, Covasna, Harghita, Mures and Sibiu) by 8.3\%, 3.54 billion euros respectively.

As also related to some previous World Bank observers' arguments, focusing at monetary data alone can be misleading in the Romanian case. It is about an "extraordinary economic activity with regard to the number of firms", which was not suggested by the amount of monetary FDI-inflows. This way, Romania managed to achieve an unexpected high export performance and to become one of the few CEECs where significant spillovers could be detected. This development was to a large extent driven by the large number of relatively small firms.

The FDI is unevenly distributed in Romania by regions ${ }^{7}$, as already mentioned above. The NBR provides some data for the Romanian development regions (NUTS2 level) for the years 2003-2006. The greenfield data is available for the years 2005 and 2006.

\footnotetext{
${ }^{7}$ As by the rule.
} 
The share of the greenfield investments among the total FDI-stock amounted to some $42.2 \%$ in 2005 and to $49.5 \%$ by 2006 . The highest share of total Greenfield FDI-stocks in 2006 was recorded in the Region Bucharest-Ilfov, followed by Center (9.6\%), the West (8.0\%), North-West (6.0\%) and maybe the South-Muntenia (5.2\%) which caught-up compared to the previous year $(4.0 \%)$.

The existing data indicate that the FDI inflow and stock grew together with another sharp increase, the one of regional disparities in favour of the BucharestIlfov region, winning no less than ten percentage points in a four years time. It is also observed that the second region favoured by FDI is West, but this is not visible in a reducing the observation to just the first line of the Romania's regional disparities. Let us call it the Bucharest-Ilfov disparity, as the most important one, in practical terms. the case is similar to the ones of countries around. The second FDI disparities level certainly concerns each region in part, together with its specificities.

The economic growth in Romania is predominant driven by small and medium sized enterprises (SMEs) which consistently account for more than $99.5 \%$ of active enterprises in Romania.

Some of the effects of the financial crisis on the SME's sector are: falling growth rates, increases in the number of bankruptcies and a fall in employment levels in the sector. This situation was caused by rises in the prices of raw materials, energy and food, liquidity and credit related problems, a marked decline in the demand for products and services, considerable variations in the exchange rate, and inflation. Thus 2008 marked the start of a reduction in international trading activity for Romanian firms. Exports decreased by $24.3 \%$, and imports by $37.4 \%$ compared to 2007. The SME sector recorded the largest decline in exports. By January 2009 SME exports had fallen by $47.0 \%$ compared to the previous year.

Taking into the consideration the key socio-economic changes in the last years and the perspectives under the crisis circumstances, the conclusions regarding Romania's convergence to $E U$ are the following:

- A higher degree of real convergence represents the substance of successful integration in European model

- In 2007, GDP/capita was 34\% relative to the EU-27 average less than Czech Republic (75\%), Poland (51\%), Hungary (63\%), Slovenia (83\%), but more than Bulgaria (33\%), despite the fact that $\mathrm{R}$ had one of the highest growth rate in Europe (in 2004 it was $8,4 \%$ )

- The structure of Romania economy sectors shows that it remained constant during 1995-2007, Romania has the lowest structural convergence indicator among ex-communist countries (50\%), while the average of ECE countries was $75 \%$ and Bulgaria has $68 \%$. The explication: the poor tertiary sector contribution to the GDP (in 2005, was 50\% in Romania, versus $72 \%$ in EU-15)

- Romanian employment index for the convergence to the EU-15 26\% versus 65$70 \%$ in EU-27

- Romania produces with higher energy consumption, 6,5 times higher than EU average. 
- Romania has the lowest road network from the EU-27 countries, 41 times lower than in Germany

- In Romania (2004), gross average salary is only 271 Euro, 10 times lower than UE-27 (2888Euro)

In the above context we'd like to mention some short conclusions and solutions of catching-up (convergence):

- Many structural problems in Romanian economy can be solved though efficient policy to attract FDI and a good capacity to European funds absorption (around $4 \%$ ) (cohesion and structural funds)

- Since 2004, Romania has become one of the most important beneficiaries of FDI in the region. While at the end of the last decade it accounted for around 5\% of total FDI targeting the CEE region, from 2003 to 2005 this figure has more than tripled, reaching roughly $15 \%$ of total FDI directed to CEE, 2006 has been a record year in this respect, according to Central Bank data (Figure 2).

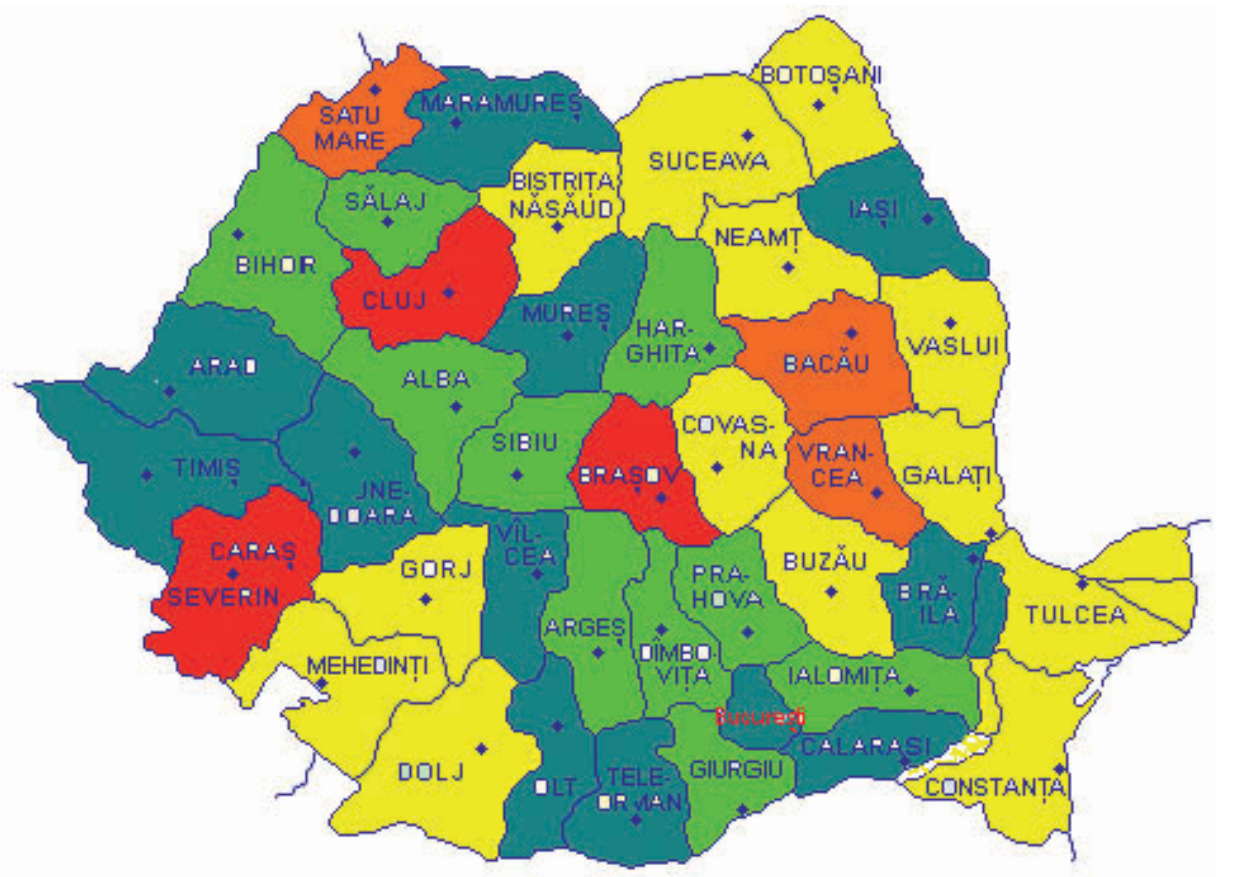

$\square \quad$ County in which it can be invested with confidence

$\square \quad$ County which should not be avoided by investors

County in which it can be invested but with care

County in which various obstacles and problems may arise for investors

County which would be prudent to be avoided by investors

Figure 2. What are the most attractive areas for investment? 


\section{REFERENCES}

Andrei, D. (2008), The foreign direct investment in Romania, in the perspective of joining the EU., Ph.D. These defended in 2008, Unpublished.

Andrei, D. (2008), Direct foreign investments in Romania. Current stage of foreign investments and foreign participation to the home company's capital subscribed, Institute for Economic Forecasting and Internet Securities Inc., ISI Emerging Markets, Barometer of the Romanian Economy, < http://dp.securities.ro>

Andrei, L. C. (2009), Economie europeană, Editura Economică, Bucharest.

ARIS (2008), Foreign direct investments in Romania.

Bîrsan, M., (1995), Integrarea economică europeană, Vol. 1, Introducere $\hat{\imath}$ teorie şi practică, Carpatica, Cluj-Napoca.

Bîrsan, M., (1999) Integrarea economică europeană, Vol. 2, Uniunea EuropeanRelații economice cu alte zone, (2007), The CDIMM Fundation Publishing House, Maramureş Corduneanu, Carmen \& Iovu, Laura Larisa, FDI and regional development in Romania, RePEc.

Socol, C. and Socol, A. G. (2007), Romania's real convergence to EU-dream or reality, Theoretical and Applied Economics Supplement, 61-72.

EC, (2006), Study of FDI and regional development. The 2006 final report.

Zaman, G. (2007), Strategic milestones of Romania's integration to the European Union process efficiency, Theoretical and Applied Economics Supplement, 11-18.

Government Ordinance No. 182/1991—of Establishing the Romanian Development Agency.

Government Ordinance No. 67/1999-Concerning Certain Measures to Stimulate the Economic Activity.

Istrate, M. and Radu, L. (2007), EU Regional Policy-convergence and economic growth? Theoretical and Applied Economics Supplement, 247-260.

Law No. 241/1998_ of Stimulating Foreign Investments.

Law No. 332/2001 — of Investments with Significant Impact upon the Economy.

Law No. 35/1991 — of Foreign Investments in Romania.

Law No. 71/1994 — of Granting Certain Facilities to the Foreign Investments.

National accounts on region, (2009), National Statistic Institute.

Păuna, C. B., Dumitrescu, I. Frentz, G., Jula, D. (2002), Politica de dezvoltare Regională în perspectiva Aderării României la Uniunea Europeană, CIDE, Bucureşti.

Păuna, C. B. and Andrei, D. (2003), Dimensiunea regională a determinarii riscului investițiilor directe străine în România, Academia Română, <http://www.icmpp.ro/ institute/contributii stiintifice.htm >

Popa, A. (2007), The FDI in Romnia-contradictory trends, Editura Economica, Regional Operational Programme, (ROP), 2007-2013, Ministerul Dezvoltarii Regionale

Statistical Yearbook Romania, INS, Bucureşti.

Vocalis, M. D. (2007), Regional disparities in Romania — an analysis of the FDI efficiency. 